\title{
KAJIAN TERHADAP KEBIJAKAN PERLINDUNGAN HAKANAK DI KABUPATEN TIMOR TENGAH SELATAN
}

\author{
Junus J. Beliu', dan Yusinta N. Fina² \\ 'Universitas Terbuka Kupang, Indonesia \\ junus@ecampus.ut.ac.id \\ ${ }^{2}$ Universitas Terbuka Kupang, Indonesia \\ yusinta@ecampus.ut.ac.id \\ Submitted: 18 June 2021 \\ Revised: 1 November 2021 \\ Accepted: 5 December 2021

\section{ABSTRACT} \\ The purpose of this study is to see how the state provides full guarantees for children \\ to develop their potential optimally, but the implementation does not go accord- \\ ing to plan. KPAI data reveals that in 2019 there were 4,369 cases of child abuse. \\ This study uses a qualitative method using descriptive methods that describe the \\ phenomena that occur in the field, observation and interviews. The results of this \\ study indicate that cultural factors, economic problems, emotional disturbances \\ and sudden behavior are the main obstacles to child protection. Therefore, protec- \\ tion of children must be carried out with a cultural approach, as well as improving \\ the quality of the community's economy in addition to law enforcement that is fair \\ to children. The implications of this research will be used as recommendations for \\ the KPAI in the south middle east district.
}

Keywords: child protection; child rights violations; law enforcement

\begin{abstract}
ABSTRAK
Tujuan penelitian ini untuk melihat bagaimana negara memberikan jaminan secara penuh kepada anak-anak untuk mengembangkan potensinya secara optimal, tetapi pelaksanaannya tidak berjalan sesuai dengan perencanaannya. Data KPAI mengungkapkan bahwa tahun 2019 telah terjadi 4.369 kasus pelanggaran gak anak. Penelitian ini menggunakan metode kualitatif dengan menggunakan metode deskriptif yang menggambarkan fenomena-fenomena yang terjadi dilapangan, observasi dan wawancara. Hasil penelitian ini menunjukkan bahwa faktor budaya, masalah ekonomi, gangguan emosional dan perilaku tiba - tiba merupakan penghambat utama perlindungan terhadap anak. Oleh karena itu, perlindungan kepada anak harus dilakukan dengan pendekatan budaya, serta peningkatan kualitas perekonomian masyarakat disamping penegakan hukum yang adil bagi anak. Implikasi dari penelitian ini akan dijadikan rekomendasi bagi pihak KPAI diwilayah kabupaten timur tengah selatan.
\end{abstract}

Kata Kunci: perlindungan anak; pelanggaran hak anak; penegakan hukum

\section{PENDAHULUAN}

Anak memiliki hak yang sama dan dilindungi oleh negara. Hal ini sesuai dengan apa yang tertulis dalam Deklarasi Universal Hak Asasi Manusia (Pasal 1) yang menyatakan bahwa semua manusia dilahirkan bebas dan setara dalam martabat dan hak asasi manusia. Mereka dikaruniai akal dan hati nurani yang baik dan harus dipersatukan dalam semangat persaudaraan(Rumtianing, 2016)

Tujuan Pembangunan Berkelanjutan (SDGs) 2030, tahun ini berfokus pada pendidikan (SDG 4) dan masyarakat yang damai (SDG 16), termasuk pemberantasan kekerasan di sekolah. Dari agenda Pemabangunan memberi slogan "tidak meninggalkan seorang pun" men- jadi jantung pembangunan berkelanjutan 2030 . SDGs dengan berfokus pada konvensi PPB terkait Hak Anak (CRC). Bagi Bangsa Indonesia, masalah perlindungan merupakan suatu hal yang mendapat perhatian serius oleh berbagai elemen bangsa. Hal ini perlu disadari bahwa anak merupakan generasi penerus yang perlu diberikan jaminan untuk mengembangkan potensinya demi keberlangsungan kehidupan bangsa ke depan. Di pundak anak - anak masa depan bangsa dipertaruhakan. Data SDG 2030 untuk anak-anak memproyeksikan kemajuan SDG jangka panjang diantara anak-anak berdasarkan SG Beseline Report on Children.(Astuti \& Suhendi, 2014)

Undang-Undang Perlindungan Anak yang 
dicetuskan pada tahun 2014 merupakan produk yang dibuat oleh bangsa Indonesia untuk memberikan jaminan bagi tumbuh kembang anak baik fisik maupun mental. Negara memberikan segala jaminan agar anak mengembangkan potensinya secara optimal sesuai dengan potensinya(Hasibuan, 2019).

Namun pada kenyataannya hal tersebut belum dilakukan secara maksimal: data dari Komisi Perlindungan Anak Indonesia (KPAI) mengungkapkan ada 4.369 kasus pelanggaran hak anak di tanah air ditahun 2019. KPAI menyajikan data, jumlah tersebut mengalami penurunan sebesar 5,5\% dibandingkan data 2018 sebanyak 4.885 kasus. Kasus tertinggi ditemukan melibatkan anak yang berkonflik dengan hukum, dengan total 1.251 kasus. Untuk lebih jelasnya lihat Tabel 1.

Tabel 1. Jenis Pelanggaran Hak Anak

\begin{tabular}{lr}
\hline \multicolumn{1}{c}{ Jenis Pelanggaran } & $\begin{array}{c}\text { Jumlah } \\
\text { Kasus }\end{array}$ \\
\hline Anak berhadapan dengan kasus hukum & 1.250 \\
Pelanggaran hak anak dalam keluarga & 896 \\
dan pengasuhan alternatif & \\
Pornografi dan kejahatan siber & 653 \\
Kesehatancdan Narkoba & 344 \\
Pendidikan yang bermasalah & 321 \\
Masalah-masalah Sosial & 291 \\
Perdagangan manusia dan eksploitasi & 244 \\
Agama dan budaya & 193 \\
Pelanggaran hak sipil dan partisipasi & 108 \\
Kasus Lainnya & 68 \\
\hline Jumlah & 4.369 \\
\hline
\end{tabular}

Provinsi Nusa Tenggara Timur (NTT) digolongkan sebagai provinsi dengan tingkat kekerasan terhadap anak yang tinggi. Menurut Ketua Lembaga Perlindungan Anak (LPA) NTT Veronika Atta,SH. MH. Kekerasan terhadap anak di NTT sudah sangat meresahkan. Berbagai kasus selalu terjadi bukan saja di rumah tetapi sudah merambat sampai ke tempat - tempat atau lembaga publik terutama sekolah. Kekerasan terhadap anak ini menurutnya, didominasi oleh pelaku yang merupakan orang - orang dekat seperti orang tua, keluarga, guru, teman dan hanya sedikit yang tidak dikenal. (Astuti \& Suhendi, 2014)

Catatan Komnas Perempuan Tahunan yang dilaporkan mengungkapkan bahwa kekerasan terhadap anak mengalami peningkatan yang cukup signifikan selama lima tahun terak- hir. Komnas perempuan mencatat bahwa kasus kekerasan terhadap perempuan di Indonesia Timur cukup banyak dengan NTT tertinggi yaitu 677 kasus.Kekerasan terhadap wanita pada wilayah bagian Indonesia Timur relative cukup banyak, dimana daerah NTT memiliki nilai tertinggi secara signifikan yaitu sebesar 677 kasus pertahun. Pada tahun 2020, kekerasan terhadap wanita dan anak yang diperoleh berdasarkan Dinas perlindungan perempuan dan anak meningkat dengan penambahan kasus 255 yang teridentifikasi pada 12 kabupaten. (Prakoso, 2016)

Data menunjukkan bahwa Kabupaten Timor Tengah Selatan sebagai salah satu kabupaten di NTT memiliki tingkat kekerasan terhadap perempuan dan anak yang cukup sangat tinggi. Ini mengindikasikan bahwa implemenatasi undang - undang perlindungan anak masih belum optimal diterapkan dalam kehidupan berbangsa dan bernegara. Untuk lebih jelas dapat dilihat pada Tabel 2.

Tabel 2. Jumlah Kekerasan Perempuan dan Anak Per Kabupaten Tahun 2020

\begin{tabular}{lr}
\hline \multicolumn{1}{c}{ Jenis Pelanggaran } & Jumlah Kasus \\
\hline Kota Kupang & 56 \\
Kabupaten Kupang & 8 \\
Alor & 7 \\
Belu & 13 \\
Ende & 46 \\
Flores Timur & 1 \\
Rote Ndao & 2 \\
Sabu Raijua & 5 \\
Sumba Tengah Selatan & 1 \\
Timur Tengah Selatan & 57 \\
Timur Tengah Utara & 58 \\
\hline Jumlah & $\mathbf{2 5 5}$ \\
\hline
\end{tabular}

Kebijakan publik, sebagaimana diketahui dalam Dyes (1981), adalah segala sesuatu yang dipilih oleh pemerintah untuk dilakukan atau tidak dilakukan. yang berarti Dye ingin mengklaim bahwa semua aktivitas pemerintah, baik eksplisit maupun implisit, adalah kebijakan. Hal ini menunjukkan bahwa sikap pemerintah yang aktif maupun passsif dalam sebuah masalah publik menunjukkan sikap pemerintah, walaupun cenderung sikap pemerintah dianggap sebagai sikap politis. (Lind \& Arndt, 2017). Dalam definisi kebijaka publik mengandung pengertian bahwa (1) kebijakan publik dibuat oleh instansi pemerintah, bukan organisasi swasta; (2) Ke- 
tertiban umum mengacu pada keputusan yang dibuat oleh lembaga pemerintah. Lebih lanjut James E. Anderson mendefinisikan politik sebagai perilaku sejumlah aktor (pejabat, kelompok, penguasa) atau sejumlah aktor dalam bidang kegiatan tertentu.(Rulinawaty, Aripin, Samboteng, \& Andriyansah, 2020)

Cakupan kebijakan publik sangat luas karena mencakup berbagai sektor atau bidang pembangunan, seperti kebijakan publik di bidang pendidikan, pertanian, kesehatan, transportasi, pertahanan, dll. bersifat lokal, seperti undang-undang, peraturan pemerintah, peraturan pemerintah provinsi , peraturan pemerintah kabupaten/kota, dan keputusan bupati/walikota. (Samboteng \& Rulinawaty, 2019)Kebijakan publik sebagaimana diuraikan di atas, tidak lahir begitu saja, melainkan melalui proses atau tahapan yang cukup panjang. Menurut Amir (2020) proses kebijakan publik meliputi 1) identifikasi masalah politik, 2). Agenda setting, 3) perumusan kebijakan), 4). ratifikasi politik (political legitimation), 5). Implementasi kebijakan dan 6). Penilaian kebijakan (policy assessment).(Hupe \& Hill, 2007) Sementara itu, aktor atau aktor dalam perumusan kebijakan publik dapat dibedakan menjadi dua kelompok, yaitu aktor resmi dan aktor tidak resmi. Peserta resmi adalah wakil pemerintah (birokrasi), presiden (eksekutif), legislatif dan yudikatif. Aktor-aktor tidak resmi saat ini antara lain: kelompok kepentingan, partai politik, dan individu warga negara.(Amir, 2020)

Implementasi kebijakan memiliki pandangan yang luas, sebagai salah satu proses dari tiga proses dari kebijakan publik, setekah keijakan disahkan oleh pemerintah menjadi regulasi yang harus dipatuhi dan dilaksanakan. Dalam pelaksanaan implementasi kebijakan melibatkan perbagai pemangku kepentingan yang terlibat, yang secara sadar bekerja bersama-sama unutk menyukseskan kebijakan publik agar mencapai kinerja kebijakan sesuai dengan tujuan kebijakan(Publik, Kebijakan, \& Kebijakan, n.d.). Implementasi kebijakan publik menjadi hal yang riskan, karena sering mengalami kegagalan, karena implementasi kebijakan publik melibatkan masyarakat dan juga melibatkan level terendah dalam birokrasi taua organisasi yang cenderung tidak memahami tujuan kebijakan. Implemen- tasi kebijakan yang sukses akan memberi dampak pada perubahan atau penyelesaian masalah yang kompleks. Perlu dipahami bahwa kebijakan publik lahir dari adanya penyakit masyarakat yang perlu diobati atau perlu diselesaikan masalahnya. (Rulinawaty et al., 2021). Implementasi kebijakan menjadi upaya untuk menjalankan perintah kebijakan (Rulinawaty Kasmad, Samboteng, \& Mahsyar, 2019) untuk mencapai tujuannya.

Implementasi merupakan tahapan yang paling penting karena pada saat implementasi kebijakan seringkali timbul masalah-masalah besar yang membatasi efektifitas kebijakan. Dalam mengimplementasikanprogram memerlukan anggaran sebagai bagian yang direncanakan. Anggaran adalah rencana rinci mengenai perolehan dan penggunaan sumber daya keuangan dan lainnya selama periode waktu tertentu. Implementasi terkait biaya kebijakan memiliki dampak langsung berpengaruh pada penyelenggaraan kebijakan. Pengeluaran yang tidak memiliki hubungan langsung dengan penyelenggaraan kebijakan dapat disebut sebagai pemborosan atau pengeluaran yang dapat telah dicegah.

Secara teoritis Dalam bukunya Kebijakan Publik, implementasi kebijakan publik sebagai cara bagi suatu kebijakan untuk mencapai tujuannya. Tidak lebih dan tidak kurang.Lebih lanjut, (Kotnik, Umek, Kovač, Stanimirović, \& Vintar, 2020) implementasi adalah proses umum dari tindakan administratif yang dapat diperiksa pada tingkat program tertentu. Proses penerapan kebijakan, dipengaruhi oleh isi atau konteks dan konteks kebijakan. Isi kebijakan terdiri dari (1) kepentingan yang terpengaruh. (2) Jenis manfaat. (3) Tingkat yang diharapkanmengubah. (4) Lokasi pengambilan keputusan. (5) Melaksanakan program. (6) Sumber Daya terlibat. (Amir, 2020)

Ada beberapa tantangan yang mempengaruhi keberhasilan implementasi Banyak faktor yang melekat pada area kontekstual yang berbeda mempengaruhi jalannya peristiwa di arena kebijakan, di samping tekanan dari aktor kebijakan internasional, nasional, regional atau lokal, dan itu membuat proses pembuatan kebijakan menjadi sangat kompleks dan bahkan lebih menarik. Koherensi kebijakan vertikal dan horizontal merupakan tantangan tambahan, sedangkan koordinasi dan pengelolaan kebijakan publik 
J1AD: Jurnal Ilmu Administrasi dan Pemerintahan Indonesia Volume 02 No 02 December 2021

Pages 73-80

yang bersifat lintas sektoral sangat sulit. Selain itu, biasanya tidak ada alokasi publik yang memadai untuk pengembangan dan implementasi kebijakan yang efektif, yang sering kali mengarah pada solusi dan improvisasi ad-hoc. Untuk alasan yang sama, penilaian dan evaluasi yang komprehensif dan rinci tentang efek atau hasil yang diharapkan dari kebijakan publik jarang dilakukan.

Di sisi politik dari spektrum kebijakan publik, orientasi ideologis, kepentingan partai dan kesepakatan koalisi memainkan peran besar dalam konteks pembuatan kebijakan, sementara opini profesional dan publik sering diabaikan dan diabaikan. Pola pikir semacam ini yang dengan murah hati didukung oleh tradisi budaya dan politik nasional, berulang kali menyebabkan kurangnya orientasi strategis yang realistis dan koheren serta rencana aksi yang layak.

Proses pembuatan kebijakan yang tidak terstruktur dengan baik dan sering dipandu secara sewenang-wenang secara tidak langsung menyebabkan keputusan yang tidak berdasar dan tidak masuk akal, dan selanjutnya mengurangi minat profesional dan masyarakat umum dalam debat publik, proses deliberatif, dan masalah yang sedang dibahas. Komunikasi antara otoritas publik dan masyarakat umum bersifat sepihak dan agak terbatas, dan dengan demikian tidak efektif. Oleh karena itu, masyarakat umum biasanya memiliki harapan yang tidak realistis tentang kebijakan tertentu dan semakin kecewa dan tidak puas setelah implementasinya, yang biasanya mencerminkan efisiensi kebijakan yang lebih rendah daripada yang diantisipasi.

Ranah kebijakan, di mana studi ini menawarkan analisis komprehensif holistik dari faktor kunci yang relevan untuk keberhasilan desain dan implementasi kebijakan publik, yang berlaku secara luas untuk semua atau sebagian besar bidang kebijakan.

Selama pemeriksaan berbagai teori kebijakan publik yang relevan, kami mengekstraksi faktor-faktor kunci: dukungan strategis, kelembagaan, normatif, ekonomi/keuangan, metodologi/prosedur dan organisasi/sumber daya manusia/TIK, yang kami yakini sebagai kunci keberhasilan desain, implementasi dan kinerja kebijakan publik. Akibatnya, kami menganalisis peran, sifat, dan saling ketergantungan dari faktor-faktor yang dipilih ini. Oleh karena itu, tujuan artikel ini adalah untuk menganalisis imple- mentasi kebijakan, untuk menentukan faktor mana yang telah ditentukan sebelumnya yang berkontribusi paling besar terhadap desain dan implementasi kebijakan publik yang berhasil, dan untuk memberikan dasar untuk perbandingan dengan negara atau sistem serupa. Sejalan dengan landasan teoretis, makalah kami terutama berfokus pada dua tujuan penelitian yang saling terkait:

Analisis sifat, peran dan signifikansi dari faktor-faktor yang dipilih untuk desain dan implementasi kebijakan publik yang sukses diwilayah tertentu. Investigasi saling ketergantungan dari faktor-faktor yang dipilih dan dampaknya (diurutkan berdasarkan relevansi) pada kinerja kebijakan publik.

Rancangan penelitian yang diusulkan didasarkan pada teori implementasi kebijakan publik. Dengan menghubungkan desain kebijakan dan pembuatan kebijakan dengan teori terkait, kami mencoba mengisi kesenjangan teoritis-metodologis dan berkontribusi pada pencarian model teoretis yang dapat menjelaskan dinamika implementasi kebijakan dan lingkungan serupa. Struktur makalah ini adalah sebagai berikut: pertama, kerangka konseptual teoritisanalitik berdasarkan tinjauan literatur dari teori kebijakan publik yang relevan dibahas. Berasal dari temuan-temuan ini, faktor-faktor yang relevan untuk desain dan implementasi kebijakan publik yang sukses diidentifikasi dan dipilih.

\section{Lingkungan Kebijakan Publik}

Pemimpin politik dan pembuat kebijakan, serta birokrat yang membentuk kebijakan publik, secara teratur menghadapi keputusan strategis dengan konsekuensi masa depan yang tidak pasti karena perubahan sosial yang konstan. Hasil seringkali bergantung pada berbagai faktor yang sulit diprediksi di luar kendali mereka (Volkery \& Ribeiro, 2009)

Realitas pengambilan keputusan kebijakan publik secara definisi dipenuhi dalam kondisi tingkat ketidakpastian dan kompleksitas yang tinggi. Dalam dekade terakhir, desain dan implementasi KPS telah secara kontekstual dan metodologis, diuraikan dengan baik dalam literatur akademik (Mintrom \& Luetjens, 2017) Meskipun banyak penelitian telah dilakukan sejauh ini, tanpa kecuali dilakukan di bidang kebijakan tertentu, yang berarti bahwa analisis komprehensif yang sistematis dari faktor-faktor kunci yang 
mempengaruhi proses desain dan implementasi kebijakan publik, berlaku secara luas untuk semua atau sebagian besar bidang kebijakan, masih belum ada(Howlett, 2015).

Fokus utama studi kebijakan publik, yang diklasifikasikan sebagai subbagian dari disiplin ilmu politik yang lebih luas (Cairney, 2013) telah lama bagaimana menjelaskan proses kebijakan publik dan outputnya dalam bentuk instrumen kebijakan tertentu. Para peneliti di subbidang ilmu politik ini mempelajari formasi, proses dan perkembangan pembuatan kebijakan publik dan perubahan kebijakan publik, dan bertujuan untuk mengklarifikasi mengapa pendekatan kebijakan publik tertentu tampak lebih berhasil daripada yang lain. Untuk lebih memahami kompleksitas proses kebijakan publik, peneliti secara teratur mempersempit fokus pada subset dari pemain kebijakan publik utama yang sering dimasukkan dalam pembentukan kebijakan publik di area kebijakan publik tertentu, seperti kebijakan lingkungan atau kebijakan kesehatan. Namun, lingkungan kompleks kontemporer membutuhkan (lebih) pendekatan interdisipliner yang sudah ada di tingkat pemerintahan yang lebih rendah dan bahkan lebih penting lagi di tingkat pemerintahan yang lebih tinggi (Raadschelders, 2011)

Salah satu pertanyaan yang sering diabaikan dalam ilmu politik dan administrasi publik adalah tentang hubungan menarik antara politisi dan birokrat dan bagaimana pemerintahan dan administrasi terkait satu sama lain mengasumsikan peran yang lebih besar dari administrasi publik (birokrasi) pada tahap awal proses pembuatan kebijakan.

Administrasi publik secara politik independen dari politik dalam pelaksanaan kebijakan, meskipun beberapa tingkat dikotomi di antara keduanya diperlukan Birokrasi dianggap sebagai instrumen pemerintah untuk menyiapkan legislasi dalam rangka menjawab tantangan publik melalui implementasi kebijakan yang ditargetkan dan selanjutnya evaluasi dampak kebijakan publik (Kerwin \& Furlong, 2018). Namun, pada kenyataannya, birokrasi sering memainkan peran penting dalam membentuk lingkungan kebijakan publik dan mengarahkan kebijakan publik, terutama dalam kondisi tertentu, yang mungkin timbul selama interval antara pemerintah lama dan baru terpilih, kurangnya strategi dan rencana nasional, pada kedatangan struktur politik yang tidak berpengalaman pada posisi politik yang tinggi, atau dari tindakan ideologis/politik terselubung dari birokrasi. Masalah-masalah ini dapat menjadi sangat akut di negara-negara yang secara politik tidak stabil dengan tradisi demokrasi yang pendek dan lembaga-lembaga negara yang lemah. Praktik semacam itu bisa sangat berbahaya, karena dapat meningkat menjadi defisit demokrasi yang signifikan dan anomali struktural lainnya dalam fungsi badan-badan pemerintah. Upaya mencari keseimbangan peran birokrasi itu rumit dan harus didukung oleh berbagai langkah sistemik, seperti; legislasi yang memadai, adanya pedoman strategis dan rencana aksi di bidang prioritas tindakan negara, fungsi institusi yang berkualitas, pengawasan politik (parlemen) yang konstan dan komprehensif, dialog yang efektif dengan masyarakat sipil dan organisasi non-pemerintah, dll.

\section{Siklus Kebijakan}

Pada tahun 1950-an teori siklus kebijakan publik dikembangkan oleh Harold Lasswell di Amerika Serikat, di mana ia mengajukan ide inovatif dengan menggambarkan ilmu kebijakan publik sebagai multidisiplin, pemecahan masalah dan secara eksplisit normatif. Saat ini, ada konsensus di kalangan akademisi bahwa siklus kebijakan publik terdiri dari lima tahap (Fontaine, 2011) yaitu: (1) penetapan agenda, (2) perumusan kebijakan publik, (3) pengambilan keputusan kebijakan publik, (4) implementasi kebijakan publik dan (5) evaluasi kebijakan publik. Meskipun kelimanya signifikan, tiga di antaranya - penetapan agenda, perumusan dan implementasi - sangat penting untuk memahami siklus kebijakan publik. Namun, untuk keberhasilan implementasi kebijakan publik dan adaptasinya yang berkelanjutan, adalah sangat penting untuk melakukan semua fase siklus kebijakan publik, termasuk evaluasi dengan langkah-langkah pemasyarakatan, untuk mengikuti prinsip-prinsip tata kelola publik yang sehat, lagi-lagi di berbagai bidang politik. serta tingkat administrasi (Ongaro \& Van Thiel, 2018)

\section{METODE}

Makalah ini menggunakan desain penelitian analisis konten penjelas dan eksploratif didukung oleh tinjauan luas literatur dan investigasi dari berbagai sumber berisi konten terkait masalah. Metode analisis isi diterapkan pada 
terstruktur wawancara dan diskusi berorientasi objek dengan para ahli terkemuka di bidangnya. Penelitian tentang peran dan pentingnya faktorfaktor yang dipilih untuk desain yang sukses dan implementasi kebijakan publik perlindungan anak di NTT dan saling ketergantungan serta dampaknya terhadap kinerja kebijakan publik dilakukan pada bulan Februari hingga September 2020.

Pemilihan metode penelitian disesuaikan dengan kekhasan penelitian masalah dan implikasinya (Oaks, Aberdeen, \& Psychology, 2013). Karena penelitian ini sebagian besar bersifat eksploratif, metode empiris kuantitatif dapat idak memberikan hasil yang memuaskan. Oleh karena itu, analisis konten dianggap yang palingpendekatan metodologis yang menguntungkan dalam memahami bidang penelitian yang kompleks ini.

Wawancara terstruktur digunakan sebagai teknik pengumpulan data utama selama formatif fase penelitian.

\section{HASIL DAN PEMBAHASAN}

Masalah perlindungan anak merupakan masalah yang sangat krusial karena hal ini didasari oleh pemikiran bahwa setiap anak sejak lahir memiliki hak dasar yang harus dilindungi. Negara memiliki kewajiban untuk melindungi hak anak karena pada dasarnya, hak hidup, tumbuh dan berkembang merupakan hak dasar setiap manusia. Setiap aturan yang dibuat sebagai pedoman bagi keselarasan hidup manusia. Kehadiran UU Nomor 35 Tahun 2014 tentang perlindungan anak hadir sebagai jawaban atas ketidakadilan yang terjadi kepada anak. Walaupun demikian dalam pelaksanaannya banyak hal yang belum sesuai dengan harapan dari pembuat kebijakan. Hal ini tidak lepas dari anggapan bahwa untuk mengetahui layak tidaknya suatu kebijakan dilaksanakan maka akan teruji saat dilakukan implementasi kebijakan.

Masyarakat Kabupaten TTS belum sepenuhya menyadari dan mengetahui bahwa perlindungan terhadap anak merupakan hal yang sangat krusial dalam kehidupan bermasyarakat. Dalam kultur masyarakat ditemukan bahwa anak belum bisa dilibatkan dan terlibat dalam kegiatan sosial kemasyarakatan. Seseorang akan terlibat dalam kegiatan sosial bila ia telah dianggap dewasa atau telah menikah. Akibatnya, anak selalu ditempatkan sebagai pihak yang lemah dan wajib mengikuti apa kemauan dari orang dewasa. Anak seolah-olah berada dalam kelompok kelas ketiga bila anggapan bahwa perempuan menempati kelompok kelas kedua, itu adalah benar dalam masyarakat. Anak selalu diberikan kesempatan apabila laki-laki dan perempuan dewasa telah selesai dengan urusannya. Hal ini dapat dilihat ketika dalam perhelatan tertentu kesempatan untuk menikmati makan dan minum misalnya, anak selalu akan makan dan minum bila orang tua baik laki - laki dan perempuan telah selesai makan. Budaya tersebut telah menghiasi semua sendi kehidupan masyarakat akibatnya perlindungan terhadap hak anak menjadi sebuah pertentangan antara kebiasaan yang telah dijalani bertahun - tahun dengan keinginan untuk menempatkan anak sejajar dengan orang dewasa.

Kondisi perekonomian keluarga merupakan hal yang juga turut memberikan andil yang besar terhadap upaya perlindungan terhadap hak anak. Sebagai pihak yang lemah anak dikatakan wajib untuk mengikuti kemauan orang dewasa. Akibatnya, tidak jarang anak dilibatkan dalam upaya meningkatkan perekonomian keluarga. Masalah ekonomi membuat orang tua merasa bahwa kehadiran anak-anak dalam keluarga harus dimanfaatkan untuk meringankan beban perekonomian keluarga. Keberadaan anak yang seharusnya berada dalam perlindungan orang tua dimanfaatkan secara baik oleh pihak - pihak yang tidak bertanggung jawab dan mempekerjakan mereka. Markus Fallo seorang mantan pekerja anak mengungkapkan bahwa:

"Saya bersama dengan saudara yang lain kakak beradik awalnya bersekolah namun karena kondisi perekonomian orang tua tidak memungkinkan maka kami terpaksa harus berhenti bersekolah di kelas 1 SD. Hal ini disebabkan sang majikan sering memberi uang kepada bapak. Akibatnya, bila kami melarikan diri untuk tidak bekerja maka bapak selalu memarahi dan membujuk kami untuk kembali bekerja"

Sedangkan menurut pengakuan Melda seorang pekerja yang lain:

“Saya terpaksa harus bekerja karena setelah ibu saya meninggal, bapak meninggalkan kami dan tidak diketahui keberadaannya, Hal ini menyebabkan sebagai anak pertama saya 
berhenti bersekolah dan bekerja untuk mengurus ke - 5 adik yang masih kecil"

Hasil wawancara tersebut mengindikasikan bahwa eksploitasi terhadap anak lebih dipengaruhi oleh kondisi perekonomian keluarga. Masyarakat menyadari bahwa anak perlu mendapat perlindungan baik secara fisik maupun mental tetapi keterbatasan membuat mereka tidak mampu berbuat banyak untuk melindungi anak sebagai pihak yang lemah.

Selain persoalan perekonomian, tekanan emosional merupakan faktor lain yang merupakan alasan bagi orang tua untuk mengabaikan keberadaan anak dalam kehidupannya. Hal ini tidak lepas kondisi psikologis orang dewasa yang diperhadapkan pada persoalan - persoalan hidup yang kian hari terus memberatkan dan akibatnya melampiaskan kepada anak - anak sebagai pihak yang lemah.

Delila salah seorang pekerja swasta yang melakukan kekerasan terhadap anaknya saat ditemui mengungkapkan:

"saya terpaksa melakukan kekerasan terhadap korban karena saya sering dimarahi dan dicaci maki oleh majikan saya yang merupakan ibu dari korban. Saya melakukan kekerasan untuk membalas kalakuan orang tuannya"

Dari wawancara ini terlihat bahwa tekanan emosi yang tersimpan secara terus menerus menyebabkan orang bisa melakukan kejahatan terhadap anak yang masih polos dan belum memiliki kemampuan untuk membela diri. Selanjutnya, keberadaan manusia tidak dapat dilepaskan dari kondisi yang terjadi secara tiba - tiba. Manusia memiliki reflex terhadap hal - hal yang ada disekitarnya, hal ini bisa berakibat terhadap pelanggaran hak anak sebagai pihak yang lemah. Hal ini sering disadari oleh pelaku kejahatan terhadap anak yang kemudian diungkapkan penyesalan yang mendalam setelah menyadari bahwa tindakan tersebut telah dilakukan. Tidak jarang pelaku kejahatan kemudian mengungkapkan penyesalannya.

\section{SIMPULAN}

Masalah perlindungan anak merupakan masalah yang sangat krusial karena hal ini didasari oleh pemikiran bahwa setiap anak sejak lahir memiliki hak dasar yang harus dilindungi.
Negara memiliki kewajiban untuk melindungi hak anak karena pada dasarnya, hak hidup, tumbuh dan berkembang merupakan hak dasar setiap manusia. Setiap aturan yang dibuat sebagai pedoman bagi keselarasan hidup manusia. Kehadiran UU Nomor 35 Tahun 2014 tentang perlindungan anak hadir sebagai jawaban atas ketidakadilan yang terjadi kepada anak. Faktor yang menghambat implementasi UU perlindungan anak adalah budaya, masalah ekonomi, gangguan kejiwaan dan situasi yang terjadi secara tiba - tiba. Oleh karena itu, perlindungan kepada anak harus dilakukan dengan pendekatan budaya, serta peningkatan kualitas perekonomian masyarakat disamping penegakan hukum yang adil bagi anak.

\section{DAFTAR PUSTAKA}

Amir, A. (2020). Public Policy Implementation: Study on Educational Budgeting of Palopo. Journal La Sociale, 1(1), 5-11. https://doi.org/10.37899/journalla-sociale.v1i1.19

Astuti, M., \& Suhendi, A. (2014). Implementasi Kebijakan Kesejahteraan Dan Perlindungan Anak Implementation of Welfare and Child Protection Policies. Sosio Konsepsia, 4(1 (September-Desember)), 215-235.

Cairney, P. (2013). Standing on the Shoulders of Giants: How Do We Combine the Insights of Multiple Theories in Public Policy Studies? Policy Studies Journal, 41(1), 1-21. https://doi.org/10.1111/psj.12000

Fontaine, G. (2011). The effects of governance modes on the energy matrix of Andean countries. Energy Policy, 39(5), 2888-2898. https://doi.org/10.1016/j.enpol.2011.02.064

Hasibuan, S. A. (2019). Kebijakan Pertanggungjawaban Pidana Dalam Rangka Perlindungan Hukum Bagi Anak. Jurnal Hukum Responsif, 7(7), 169-175. Retrieved from http://jurnal.pancabudi.ac.id/index. $\mathrm{php} /$ hukumresponsif/article/view/568

Howlett, M. (2015). Research Provocations. Policy and Politics, 43(2), 291-311.

Hupe, P., \& Hill, M. (2007). Street-level bureaucracy and public accountability. Public Administration, 85(2), 279-299. https://doi.org/10.1111/j.14679299.2007.00650.x

Kerwin, C. M., \& Furlong, S. R. (2018). Rulemaking: How government agencies write law and make policy. Cq Press.

Kotnik, Z., Umek, L., Kovač, P., Stanimirović, D., \& Vintar, M. (2020). Analysis of the Key Factors for Successful Public Policy Implementation: A Qualitative Study in Slovenia. Danube, 11(2), 113-140. https://doi. org/10.2478/danb-2020-0007

Lind, E. A., \& Arndt, C. (2017). Regulations, fairness and trust. https://doi.org/10.1787/9789264268920-6en

Mintrom, M., \& Luetjens, J. (2017). Creating Public Value: Tightening Connections Between Policy Design and Public Management. Policy Studies Journal, 45(1), 
J1AD: Jurnal Ilmu Administrasi dan Pemerintahan Indonesia Volume 02 No 02 December 2021 Pages 73-80

170-190. https://doi.org/10.1111/psj.12116

Oaks, T., Aberdeen, T., \& Psychology, E. (2013). Yin, R. K. (2009). Case study research: Design and methods (4th Ed.). Thousand Oaks, CA: Sage. The Canadian Journal of Action Research, 14(1), 69-71. https:// doi.org/10.33524/cjar.v14i1.73

Ongaro, E., \& Van Thiel, S. (2018). The Palgrave handbook of public administration and management in $\mathrm{Eu}$ rope. Springer.

Prakoso, A. (2016). Kebijakan Hukum Pidana Perlindungan Anak Dalam Pembaharuan sistem Peradilan Dan Pidana Anak di Indonesia. 359.

Publik, A., Kebijakan, J., \& Kebijakan, P. (n.d.). RESOURCES SHARING :

Raadschelders, J. C. N. (2011). Public administration: The interdisciplinary study of government. New York: Oxford University Press.

Rulinawaty, Aripin, S., Samboteng, L., \& Andriyansah. (2020). Capacity Building Model Of Governance Participatory Network: How Community-Based Organization Is Changing The Culture Of Local Governance In Indonesia. International Journal of Management (IJM, 11(12), 1786-1799. https://doi. org/10.34218/IJM.11.12.2020.164

Rulinawaty Kasmad, Samboteng, L., \& Mahsyar, A. (2019). The Unwise Policy Of Community Based-Organisation: Can It Empower Them? Implementation Network Of Food Diversification In Indonesia Rul- inawaty. OPCION, 35(22), 2900-2961. https://doi. org/10.1017/CBO9781107415324.004

Rulinawaty, Samboteng, L., Aripin, S., Kasmad, M. R., Harta, R., Susanti, A., \& Fadillah, S. (2021). Accountability Performance Public Service: Community Based Organization Solution for Base Public Service. Proceedings of the First International Conference on Science, Technology, Engineering and Industrial Revolution (ICSTEIR 2020), 536(Icsteir 2020), 238-243. https://doi.org/10.2991/ assehr.k.210312.037

Rumtianing, I. (2016). Kota layak anak dalam perspektif perlindungan anak. Jurnal Ilmiah Pendidikan Pancasila Dan Kewarganegaraan, 27(156), 7-23. Retrieved from http://journal.um.ac.id/index.php/ jppk/article/view/5524

Samboteng, L., \& Rulinawaty. (2019). Red Tape It's Heaven For Bureaucratic Public Services A Case Study On Trade In Services Business License Of Makassar City. International Journal of Social Science and Humanities Research, 2(8), 1-12. Retrieved from www.ijojournal.com

Volkery, A., \& Ribeiro, T. (2009). Scenario planning in public policy: Understanding use, impacts and the role of institutional context factors. Technological Forecasting and Social Change, 76(9), 1198-1207. https://doi.org/10.1016/j.techfore.2009.07.009 